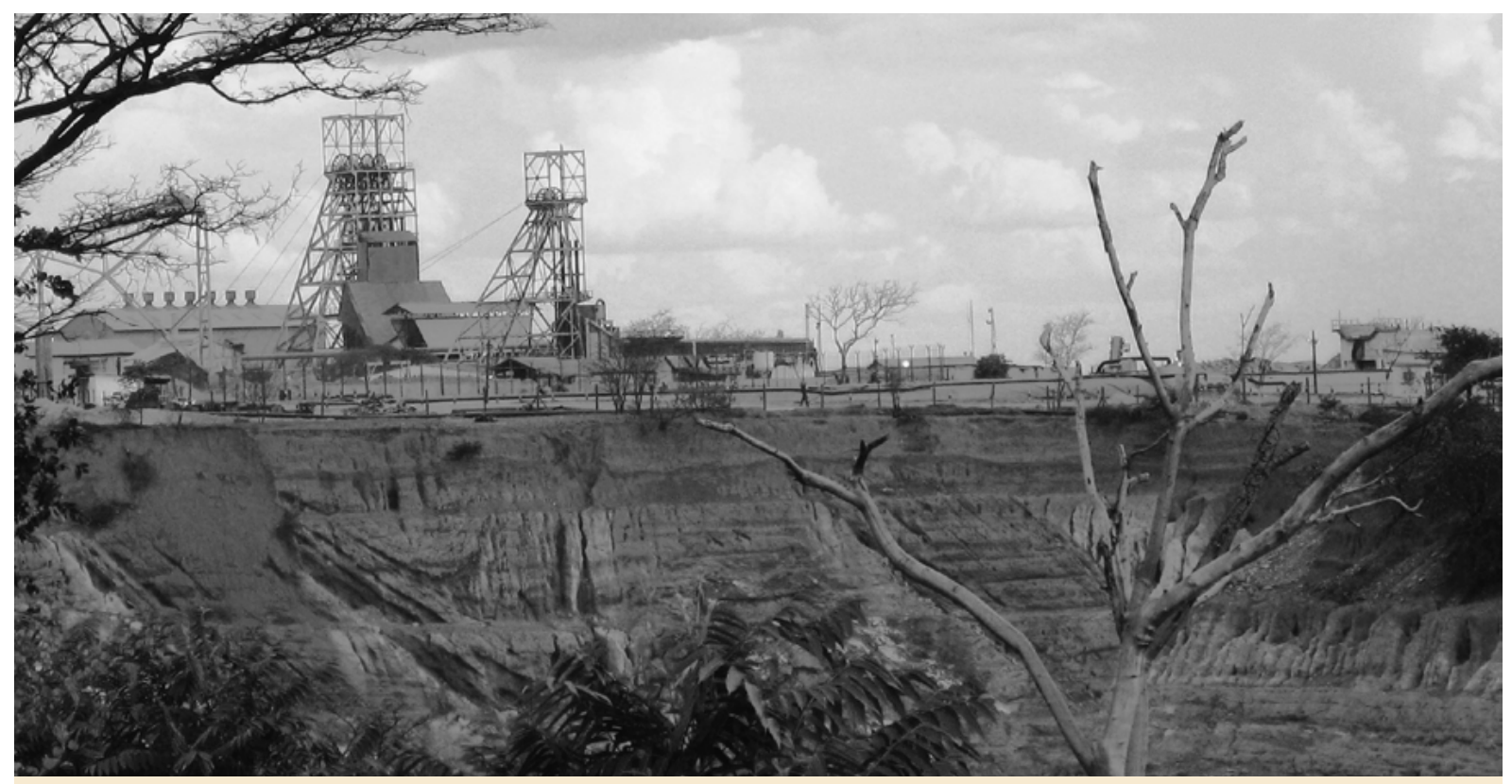

Nkana mine in Zambia is one of the largest in Africa and has been in operation since 1932. PC: Wikipedia

\section{Fighting the Race to the Bottom: \\ Regulating Chinese Investment in Zambian Mines}

\section{Mukete Beyongo Dynamic}

Following the widespread privatisation of the Zambian copper mining sector in the 1990s, several state-owned companies from China began to invest in the country. While these companies have created jobs, built valuable infrastructure, and paid taxes to the government, China's increasing presence in Zambia has also given rise to a number of concerns. Some Chinese mining companies have been accused of maintaining lax safety standards, paying low wages to local employees, and of physically abusing their workers. Critics allege that this has triggered a 'race to the bottom' in labour standards. Still, such a perspective runs the risk of being over simplistic, as it largely overlooks the agency of local actors.
Copper mining remains the dominant economic activity in Zambia, a situation that has not changed since 1928 when largescale mining was introduced in the country. According to a World Bank report released in June 2015, the sector today accounts for more than sixty-five per cent of Zambia's export earnings and eleven per cent of its gross domestic product (The World Bank 2015). However, while the World Bank detailed the benefits of the sector to the economy, another more critical report released at the same time by the Office of the Auditor General of Zambia found that the mining sector has seen the largest number of industrial accidents and fatalities in post-colonial Zambia (Auditor General 2015). For this reason, finding a way to mitigate risks to worker safety while increasing copper production has become a paramount public concern in the country.

The widespread privatisation of the Zambian copper mining sector in the 1990s led to the re-emergence of foreign mining companies in the country, including several state-owned companies from China. While these Chinese companies have created 
jobs, built valuable infrastructure, and paid taxes to the government, China's increasing presence in Zambia has also given rise to a number of concerns. Some Chinese mining companies have been accused of maintaining lax safety standards, paying low wages to local employees-especially if compared to other foreign mining companies-and of physically abusing their workers (Blair 2006). For these reasons, critics have accused the Zambian government of weakening its safety standards to attract foreign investors, of failing to monitor compliance with safety and labour laws, and of underfunding local regulators (Haglund 2008).

These critics allege that this has triggered a 'race to the bottom' in labour standards. By 'race to the bottom', they refer to a tendency where the government reduces the monitoring and enforcement capacity of public regulatory institutions, or enacts lax safety laws, in order to attract foreign investors. They not only argue that the Zambian government weakens safety standards through funding cuts, but they also claim that current regulatory standards are obsolete and that the government intervenes in the decision-making process of regulators to protect Chinese companies from paying penalties when they fail to comply with local regulations. Still, such a perspective runs the risk of being over simplistic, as it largely overlooks the agency of local actors.

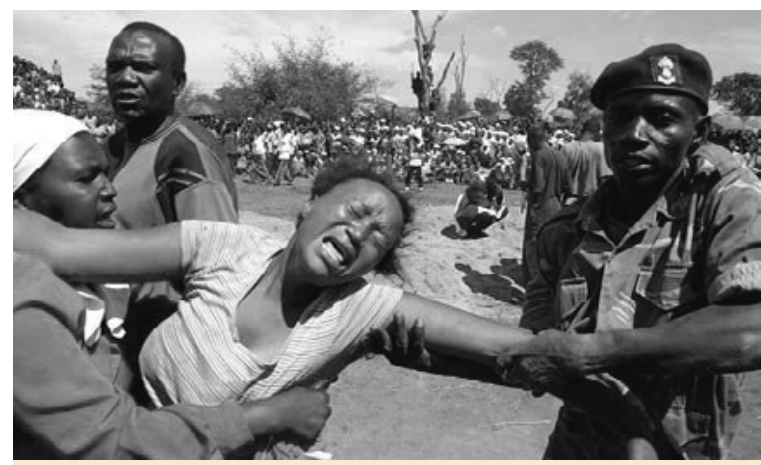

A woman in despair at the funeral of fifty-one workers who were killed at a Chinese-owned copper mine in Zambia in 2005. PC: Salim Henry

\section{The Roots of the iscontent}

In April 2005, fifty-two Zambians were killed in an accident in an explosives factory jointly owned by the Beijing General Institute for Research and Metallurgy (BGRIMM) and the Non-Ferrous China-Africa (NFCA) Mining Company-both state-owned companies-in Chambishi in Zambia's Copperbelt Province (BBC 2005). One year after the accident at the BGRIMM plant, five Zambians were shot and injured by gunshots fired by their Chinese manager while they were protesting against low wages and lax safety standards at the NFCA Chambishi mine. In light of this, it is not surprising that Chinese safety and labour relations in Zambian copper mines were at the centre of Zambia's 2006 presidential election. Indeed, in a keynote speech former Zambian president Michael Sata stated that '[Chinese] labour relations are very bad. They are not adding any value to what they claim is investment; instead of creating jobs for the local workforce, they bring in Chinese workers to cut wood and carry water' (Blair 2006).

Such high-level political attention fuelled the discontent. In August 2008, more than five hundred Zambian workers attacked a newly built Chinese-owned Chambishi Copper Smelter and burnt down the kitchen of a Chinese-resident. One Chinese and three Zambians working in the kitchen were seriously injured. The protesters claimed that they had been told that the management was going on vacation and abandoning collective negotiations in which workers had demanded changes in safety standards and a reduction in work hours. In another accident that attracted a lot of media attention in 2010, a Chinese supervisor at the Collum Coal mine in Southern Province shot thirteen Zambians. The workers at the mine were complaining against the state of safety standards in the mines and their low wages. These accidents 
and protests have raised serious debate about labour and safety standards in Chinese mines in Zambia and about the local government's ability to enforce their own regulations in these contexts.

\section{The Importance of Local Actors}

The claim that Chinese companies are creating a 'race to the bottom' in labour standards, while having certain merits, ultimately simplifies the processes at play in the formulation of safety and labour regulations in Zambia. It is based on a state/ business-centred approach that ignores the role of non-state actors, such as trade unions, mine workers, local NGOs, and international organisations. The 2006 protest at the NFCA mine mentioned above is a good case in point. In June 2006, NFCA mine workers went on strike in protest against the company's refusal to implement a labour agreement it had agreed to with National Union of Mine and Allied Workers of Zambia to improve safety at its Chambishi mine. When five miners were shot in the protest, the popular reaction to the onslaught led to significant safety and labour relations reform at the mine (Sautman and Yan 2014).

In response, the NFCA launched the 'Safe Production Management System' in which Safety and Environmental Protection were restructured into a separate department. Moreover, in 2007, the NFCA introduced a company 'Safety Month' in commemoration of the incident, an event that is still being held every June. Nine years after the incident, in a company memo sent to all workers at the start of the 2015 Safety Month, the management suggested that commemorating the month of June on a yearly basis demonstrates the company's commitment to ensuring that its operations are conducted in a safe and riskfree environment. In an interview that I conducted in Chambishi Township in October
2015, a union leader at the NFCA mine told me that the 2006 protest positively changed safety and labour relations at the mine.

Furthermore, the 'race to the bottom' thesis suggests that the Zambian government is passive with regard to safety abuses in the country, or negligent of labour conflicts within Chinese mines because the authorities prioritise economic growth and investment over safety. This is far from the truth. For instance, during a parliamentary debate on 11 July 2007, in response to the 2005 BGRIMM accident, former deputy minister of Mines and Minerals Development, Maxwell Mwale, told the Zambian parliament that the government had increased the number of inspection vehicles, logistics, and staff at the Mines Safety Department (National Assembly of Zambia 2007). According to official data, inspections increased from two hundred and sixty in 2004 to 1,269 in 2014 . Furthermore, a report published in 2009 by the International Labour Organisation also highlighted labour and safety reforms undertaken in Zambia since the incident (International Labour Organisation 2009). For instance, in 2006, the government introduced an integrated labour inspection form to streamline inspections and verification of compliance; forty-five new inspectors were hired; and the administrative powers of inspectors were increased.

In addition, in 2008, 2012, and 2015, the government revised the national Employment Act. A Minimum Wage Bill was introduced in 2012, fines for non-compliance with safety standards were increased, and labour inspectors were provided with more powers to enforce labour and safety laws. In November 2007, the government established a Labour Task Force through the Ministry of Labour and Social Security to enforce and ensure adherence to national labour laws. The number of members on the task force jumped from forty-five in 2007 to ninetyone in 2009. Moreover, a new Mines and Mineral Development Act was passed in 2015 , providing officials at the Mines Safety 
Department with stronger powers to enforce and ensure that mining companies maintain a safe and healthy working environment. According to official data, industrial accidents and fatalities in mining companies have declined since 2006: the number of accidents recorded by the Mines Safety Department fell from three hundred and fifty in 2005 to 123 in 2014 , while the number of fatal accidents fell from eighty in 2005 to twelve in 2014.

\section{Challenges Ahead}

Ching Kwan Lee has claimed that 'Chinese investors [operating in Zambia] have had to climb a steep learning curve in dealing with types of politics not found in their own country' (Lee 2014, 29). The trend of injuries and fatalities in Chinese mines in Zambia recorded by the Mines Safety Department supports this claim. However, as a 2011 study by Human Rights Watch (HRW) has highlighted, Chinese mining companies in Zambia still have further reforms to make in order to strengthen their efforts to mitigate accidents (HRW 2011). These include improving the safety conditions of workers hired by subcontractors, reducing the number of casual employees, and cutting the number of working hours. A letter sent to HRW by officials from the China NonFerrous Metal Mining Company in 2011, and quoted in the same report, suggest that these reforms are gradually being introduced. Conversations between the author and mine workers at the NFCA mine indicates that as of October 2015, although safety and labour disputes between the NFCA and local unions have been normalised, some workers in Chinese companies contracted by the NFCA still work under unsafe conditions-most often without appropriate safety equipment. However, as one worker said, compared to 2006, before the BGRIMM accident and the NFCA Chambishi protest, there have been significant improvements in the enforcement of safety and labour regulations at the NFCA mine and the Chambishi Copper Smelter.

To conclude, the activities of Chinese mining companies have indeed threatened a 'race to the bottom' in labour and safety standards in Zambia. But local actors such as trade unions have organised protests, and pushed the issue into the public agenda. In response to these protests, some Chinese mining companies have altered their safety policies and normalised their relations with unions. Furthermore, under mounting public pressure, the Zambian government has introduced labour laws and established structures to strengthen its safety regulatory standards in the last decade. Nevertheless, notwithstanding the demonstrable success of these measures in reducing industrial accidents, the industrial relations system in Zambia still suffers from inadequate funding, limited human resources and capacity, and in some instances a lack of coordination among the relevant regulatory agencies.

\section{Mukete Beyongo}

Mukete Beyongo is a PhD Candidate at the Australian Centre on China in the World, the Australian National University. His research focuses on local responses to growing Chinese outbound direct investment in Zambia. He completed his undergraduate and postgraduate studies at the University of Yaounde II-Soa, Cameroon, and the Cherkassy State Technological University, Ukraine. 
This text is taken from Disturbances in Heaven: A Year of Chinese Labour, Civil Society, and Rights, Made in China Yearbook 2016, edited by Ivan Franceschini, Kevin Lin and Nicholas Loubere, published 2017 by ANU Press, The Australian National University, Canberra, Australia. 